\title{
Customer Brand Engagement in Social Commerce: A Study of Sarawak
}

\author{
Chiew Huang Ping* and Winnie Wong Poh Ming \\ Department of Marketing \\ School of Business and Management \\ University College of Technology Sarawak, \\ No. 1, Jalan Universiti, 96000 Sibu, \\ Sarawak, Malaysia. \\ Corresponding author: autumnchiew@outlook.com
}

\begin{abstract}
Due to the growth of social networking, a new business opportunity known as 'social commerce' has been created in the electronic commerce environment. This development is changing individuals' social interactions and their shopping patterns. Thus, it is important for social marketers and advertisers to understand the driver of customer brand engagement in social commerce. This study is an attempt to investigate whether attitude towards the behaviour and subjective norm have a positive effect on customer brand engagement in social commerce. The scope of the study was focussed on the clothes and accessories market in social commerce pages or groups and it was conducted in Sibu, Sarawak. The Theory of Reasoned Action was applied to capture the human behaviour of social media users connecting to the brand in social commerce. The study was conducted on quantitative basic where a survey questionnaire instrument was used for data collection. The purposive sampling method was employed to obtain accurate data from the studied samples. A total of 106 respondents were collected from social media users through a self-administered questionnaire. The Statistical Package of Social Science (SPSS) version 22 and Smart Partial Least Squares 3.0 (Smart PLS) were used as the main statistical tools. The present study implied that attitude towards the behaviour and subjective norm have a positive effect on customer brand engagement in social commerce. The findings provide valuable references for future researchers or academicians in the related social psychological fields especially in the context of social commerce. The findings also give social marketers and advertisers some ideas on what should be taken note of to gain more customers. Managerial and theoretical implications are also highlighted.
\end{abstract}

Keywords: Attitude towards Behaviour, Customer Brand Engagement, Social Commerce, Subjective Norm, Theory of Reasoned Action

\section{Introduction}

Social commerce is a business that is executed on a social platform, which often combines online and offline modes (Chen, Lu, \& Wang, 2017). It promotes the sale of products and affects user buying behaviour through the established social media and social network sites (Sharma \& Crossler, 2014). In social commerce, there is a great network of online peers including friends, strangers, colleagues or acquaintances who support the transactions by sharing their electronic shopping experience concerning the 
information of the products and services (Maia, Lunardi, Longaray, \& Munhoz, 2018). The interactivity of social networks stimulates product promotions and encourages the willingness of customers to buy (Chen, Hsiao, \& Wu, 2018). Social commerce has recently become a popular topic and some empirical studies have been conducted on the subject (Leong, Jaafar, \& Ainin, 2018; Hajli, Sims, Zadeh, \& Richard, 2017; Bao \& Volkovynska, 2016).

Unfortunately, sellers on social media channels are faced with the problem of being customer-centred as customers hold more power (Ranjan \& Read, 2014). Some companies who conduct their business in the e-commerce market are still trying to find the factors that influence the participation of customers in social commerce (Zhang, Lu, Gupta, \& Zhao, 2014; Zhou, Zhang, \& Zimmermann, 2013). Although some past studies on social commerce have explored the factors of consumer decisions, purchase intention and customer participation in social commerce (Chen, Hsiao, \& Wu, 2018; Maia, Lunardi, Longaray, \& Munhoz, 2018; Gan \& Wang, 2017; Chen \& Shen, 2015), limited research have been done to understand the factors that drive customers to engage with particular brands in social commerce. Based on the above discussion, the study aims to investigate the relationship between attitude towards behaviour and subjective norm on customer brand engagement in social commerce. To achieve the research objective, the researchers addressed the following research question:

RQ1: Does attitude towards behaviour has positive effect on customer brand engagement in social commerce?

RQ2: Does subjective norm has positive effect on customer brand engagement in social commerce?

\section{Literature Review}

\section{Customer Brand Engagement}

Customer brand engagement is indicated as active participation, which allows customers to outstrip consumption and makes them an indispensable collaborator for company success (Reitz, 2012; Evans, 2010). From a marketing perspective, customer brand engagement is considered as something positive, for instance feeling warm, as a high degree of positive engagement results in favourable behaviour and attitudes (Schamari \& Schaefers, 2015; Gummerus, Liljander, Weman, \& Pihlstrom, 2012; Brodie, Hollebeek, Juric, \& Ilic, 2011). It is clear that the concept of customer brand engagement captures the customer's behaviour towards a brand or company and illustrates how customers tend to respond to particular brands in social commerce.

\section{Attitude towards the Behaviour}

Attitude towards the behaviour is referred to an individual's perception of the behaviour including beliefs, feelings, values, and tendencies to act in certain ways (Ajzen \& Fishbein, 1980). It is the extent to which a person has a favourable or unfavourable appraisal or evaluation of the behaviour involved (Ajzen, 1991). In this study, attitude towards the behaviour is described as a customer's assessment of the desirability of using social media channels to engage with a particular brand.

\section{Subjective Norm}

Subjective norm is defined as social pressure that originates from other people whose opinion is important to an individual and influences his or her decision to perform certain 
behaviour (Fishbein \& Ajzen, 1975). These social pressures often depend on how often individuals perceive behaviour in others and how individuals agree or disagree with the behaviour performed by them (Ho, Liao, \& Rosenthal, 2015; Ajzen, 1991). In this study, subjective norm refers to the degree of pressure laid on social commerce shoppers by significant referents, and the motivation force to comply with the wishes and opinions of their referents whether to engage or not with the brand in social commerce.

\section{Underlying Theory}

Ajzen and Fishbein (1980) proposed the Theory of Reasoned Action (TRA) to test the behavioural model with the purpose of conceptualising the determinants of intentional expected behaviour (Davis, Bagozzi, \& Warshaw, 1989). The TRA has been verified to be useful in interpreting various behaviours in social psychological fields (Sable, Schwartz, Kelly, Lisbon, \& Hall, 2006; Ajzen \& Fishbein, 1980). This study applied the TRA because it has become increasingly important as a useful explanation for identifying the underlying factors of human behaviour that determine the behaviour to engage or not to engage in a particular action (Lujja, Mustafa Omar, \& Hassan, 2016). The TRA comprises three determinants of human behaviour i.e. behavioural intention, attitude towards the behaviour, and subjective norm. All these determinants were employed to construct the research framework in this study. Given that customer brand engagement appears as a form of behaviour, it is therefore applicable for this study. The present study investigated the TRA with attitude towards the behaviour and subjective norm in exploring customer brand engagement in social commerce.

\section{Hypotheses Development}

\section{Attitude towards the Behaviour}

Attitude towards the behaviour is strongly believed to influence people's behaviour and it was proved in many past studies. The greater the favourable attitude towards the behaviour, the greater an individual's intention to perform the behaviour (Azjen, 1991). Several studies confirmed that attitude towards behaviour is positively correlated with behavioural intention (Huang, 2016; Wong, Osman, Goh, \& Rahmat, 2013). Some studies conducted in the social media context also supported that attitude towards the behaviour significantly predicts behavioural intention and in turn significantly predicts actual behaviour (Sanne \& Wiese, 2018; Al-Debei, Al-Lozi, \& Papazafeiropoulou, 2013; Goh, Lada, Muhammad, Ibrahim, \& Amboala, 2011). Perhaps, attitude toward the behaviour tends to influence a customer' intention to participate or not participate in certain activities. Thus, the following hypothesis is developed:

H1: Attitude towards the behaviour is positively related to customer brand engagement in social commerce.

\section{Subjective Norm}

Subjective norm have been indicated as the most significant predictor of behavioural intention (Ayed Al-Muala, Malek Al-Majali, \& Mamdouh Al Ziadat, 2012; Tan, Ooi, Sim, \& Phusavat, 2012; Muhamad Abduh, Jarita Duasa, \& Mohd Azmi Omar, 2011). The more individuals recognise subjective norm to encourage a certain behaviour, the more likely an individual is to perform the behaviour (Potgieter \& Naidoo 2017; Al- 
Debei, Al-Lozi, \& Papazafeiropoulou, 2013). Accordingly, when other buyers share their purchase experience and preferences the individual will be influenced to get involved in social commerce (Sharma \& Crossler, 2014). With the supporting evidence provided, it is clear that subjective norm can become a driving force for customer brand engagement. Thereby, the following hypothesis is developed:

$\mathrm{H} 2$ : Subjective norm is positively related to customer brand engagement in social commerce.

\section{Methodology}

The present study was conducted within Sarawak, Malaysia. To collect quantitative data, a survey questionnaire was employed to collect primary data through self-administrative method. A purposive sampling method was applied and the data were collected from those social media users who aged between 20 to 39 years old, have an account in social networking site (e.g. Facebook, Instagram) and messaging app (e.g. Facebook messenger, Whatsapp, Webchat), and ever purchase products from any social commerce group. The sample size of the study was 106, which fulfilled the rule of thumb of Roscoe (1975), where a sample size of between 30 to 500 samples is sufficient and acceptable in most studies (Sekaran \& Bougie, 2009). The survey questionnaires were distributed to social media users aged between 20 to 39 years old, have an account in a social networking site (e.g. Facebook and Instagram) and messaging app (e.g. Facebook Messenger, WhatsApp, Webchat), and has purchased products from any social commerce group. The questionnaire was divided into two parts.

The first part consists of multiple items used to measure the constructs, namely attitude toward the behaviour, subjective norm, and customer brand engagement. Approximately 18 items were adapted from previous researchers. Nine items of customer brand engagement were adapted from Solem and Pedersen (2016). Five items of attitude towards the behaviour were developed from Huang (2016), Lada, Tanakinjal, and Amin (2009), Teo (2009), and Four items of subjective norm were drawn from Lada et al. (2009) and Teo (2009). Each of the items were measured using a seven step Likert scale ranging from 'strongly disagree', 'disagree', 'slightly disagree', 'average', 'slightly agree', 'agree', and 'strongly agree'. The second part was designed to gather the demographic information of the respondents. A total of 130 questionnaires were distributed, 119 questionnaires were collected from the respondents, and the remaining 11 questionnaires were missing, indicating a response rate of 91.5 percent. After filtering for uncompleted questionnaires, 106 completed samples were analysed using the statistical tools of Statistical Package of Social Science (SPSS) version 22 and Smart Partial Least Squares 3.0 (Smart PLS). The results of the study are reported in the following section.

\section{Findings}

\section{Descriptive analysis}

As shown in Table 1, female were the dominant samples indicated they have more interest than male on clothes and accessories market. Besides that, majority of the samples have high literacy rate with a least a college/diploma background, implied that they are knowledgeable and willing to answer all the questions in the questionnaires 
accurately. Looking into the result of monthly income, samples within the range of RM 1, 999 and below showing the highest sense of participation on social commerce.

Table 1 Profile of Respondents

\begin{tabular}{|c|c|c|c|}
\hline Profile & Category & $\begin{array}{l}\text { Frequency } \\
(\mathbf{N}=\mathbf{1 0 6})\end{array}$ & Percentage \\
\hline \multirow{2}{*}{ Gender } & Female & 70 & 66.0 \\
\hline & Male & 36 & 34.0 \\
\hline \multirow[t]{4}{*}{ Age } & 20-24 years old & 36 & 34.0 \\
\hline & 25-29 years old & 35 & 33.0 \\
\hline & $30-34$ years old & 22 & 20.8 \\
\hline & $35-39$ years old & 13 & 12.3 \\
\hline \multirow[t]{5}{*}{ Education background } & SPM & 16 & 15.1 \\
\hline & STPM /Certificate & 5 & 4.7 \\
\hline & College/Diploma & 44 & 41.5 \\
\hline & Bachelor's degree & 36 & 34.0 \\
\hline & Master's degree & 5 & 4.7 \\
\hline \multirow[t]{6}{*}{ Monthly income } & RM 1,999 and below & 56 & 52.8 \\
\hline & RM2,000-RM2,999 & 18 & 17.0 \\
\hline & RM3,000-RM3,999 & 24 & 22.6 \\
\hline & RM4,000-RM4,999 & 6 & 5.7 \\
\hline & RM5,000-RM5,999 & 1 & 0.9 \\
\hline & RM15,000 and above & 1 & 0.9 \\
\hline \multirow{5}{*}{$\begin{array}{l}\text { Frequency of online shopping in } \\
\text { social commerce pages/group }\end{array}$} & Once a day & 6 & 5.7 \\
\hline & Once a week & 18 & 17.0 \\
\hline & Several times in a week & 27 & 25.5 \\
\hline & Once in a month & 14 & 13.2 \\
\hline & Sometimes in a month & 41 & 38.7 \\
\hline \multirow{6}{*}{$\begin{array}{l}\text { Average hour spend on social } \\
\text { commerce group per week }\end{array}$} & Less than 1 hour & 21 & 19.8 \\
\hline & $1-2$ hours & 29 & 27.4 \\
\hline & 3-4 hours & 36 & 34.0 \\
\hline & $5-6$ hours & 13 & 12.3 \\
\hline & $7-8$ hours & 4 & 3.8 \\
\hline & More than 8 hours & 3 & 2.8 \\
\hline \multirow{5}{*}{$\begin{array}{l}\text { Number of online purchase in the last } \\
3 \text { months }\end{array}$} & None & 0 & 0.0 \\
\hline & $1-5$ times & 82 & 77.4 \\
\hline & $6-10$ times & 19 & 17.9 \\
\hline & $11-15$ times & 4 & 3.8 \\
\hline & More than 15 times & 1 & 0.9 \\
\hline
\end{tabular}

Source: Author

\section{Measurement Model Assessment}

Eighteen items were used to measure the latent variables of the study. A confirmatory factor analysis (CFA) was carried out to measure the internal consistency, convergent validity, and discriminant validity for the indicators. Items loading were practically significant at a minimum cut-off point of 0.50 (Hair, Wolfinbarger, Ortinau, \& Bush, 2010). A Cronbach's alpha which is equal to or greater than 0.70 is generally acceptable (Cronbach, 1951); composite reliability and average variance extracted (AVE) should excess 0.50 (Barclay, Thompson, \& Higgins, 1995). The findings of convergent validity revealed that all the indicators were above the minimum acceptable values (refer to Table 1).

Under discriminant validity, two methods are employed, which are the FornellLarcker Criterion and Heterotrait-Monotrait Ratio (HTMT) (refer to Table 2 and Table 
3). This study indicated that no discriminant validity problem existed as the value of HTMT was greater than 0.85 (Kline, 2011) or 0.90 (Gold, Malhotra, \& Segars 2001).

Table 2 Convergent Validity

\begin{tabular}{|c|c|c|c|c|c|}
\hline $\begin{array}{c}\text { Latent } \\
\text { Variables }\end{array}$ & Items & Loadings & $\begin{array}{c}\text { Cronbach's } \\
\text { Alpha }\end{array}$ & $\begin{array}{c}\text { Composite } \\
\text { Reliability }\end{array}$ & $\mathbf{A V E}^{\mathbf{b}}$ \\
\hline Customer & CBE_1 & 0.706 & 0.915 & 0.929 & 0.595 \\
\hline Brand & CBE_2 & 0.657 & & & \\
\hline \multirow[t]{7}{*}{ Engagement } & CBE_3 & 0.836 & & & \\
\hline & CBE_4 & 0.822 & & & \\
\hline & CBE_5 & 0.802 & & & \\
\hline & CBE_6 & 0.833 & & & \\
\hline & CBE_7 & 0.758 & & & \\
\hline & CBE_8 & 0.710 & & & \\
\hline & CBE_9 & 0.796 & & & \\
\hline \multirow{5}{*}{$\begin{array}{c}\text { Attitude } \\
\text { towards the } \\
\text { Behaviour }\end{array}$} & Att_1 & 0.820 & 0.910 & 0.933 & 0.737 \\
\hline & Att_2 & 0.907 & & & \\
\hline & Att_3 & 0.906 & & & \\
\hline & Att_4 & 0.837 & & & \\
\hline & Att_5 & 0.816 & & & \\
\hline \multirow{4}{*}{$\begin{array}{c}\text { Subjective } \\
\text { Norm }\end{array}$} & Sub_1 & 0.766 & 0.895 & 0.928 & 0.764 \\
\hline & Sub_2 & 0.915 & & & \\
\hline & Sub_3 & 0.927 & & & \\
\hline & Sub_4 & 0.880 & & & \\
\hline
\end{tabular}

Note:

a. Composite Reliability $(\mathbf{C R})=$ (square of the summation of the factor loadings $) /\{$ (square of the summation of the factor loadings) + (square of the summation of the error variances) $\}$

b. Average Variance Extracted $(\mathbf{A V E})=$ (summation of the square of the factor loadings $) /$ ( (summation of the square of the factor loadings) + (summation of the error variances) $\}$

Source: Author

\section{Table 3 Fornell-Larcker Criterion}

\begin{tabular}{llccc}
\hline & & $\mathbf{1}$ & $\mathbf{2}$ & $\mathbf{3}$ \\
\hline 1. & Attitude towards the Behaviour & $\mathbf{0 . 8 5 8}$ & & \\
2. & Customer Brand Engagement & 0.601 & $\mathbf{0 . 7 7 1}$ & \\
3. & Subjective Norm & 0.673 & 0.641 & $\mathbf{0 . 8 7 4}$
\end{tabular}

Note: Diagonals represent the square root of the average variance extracted (AVE) while the other entries represent the correlations.

Source: Author

Table 4 Heterotrait-Monotrait Ratio (HTMT)

\begin{tabular}{lllll}
\hline \multicolumn{2}{l}{} & $\mathbf{1}$ & $\mathbf{2}$ & $\mathbf{3}$ \\
\hline 1. & Attitude towards the Behaviour & & & \\
2. & Customer Brand Engagement & 0.637 & & \\
3. & Subjective Norm & 0.747 & 0.682 & \\
\hline
\end{tabular}

Source: Author

\section{Structural Model Assessment}

Drawing from bootstrapping, the findings of the hypotheses testing were illustrated in Figure 1, Table 4, and Table 5. The t-values (robust scores) should be above 1.96 or 2.56 at the significant level of 0.05 and 0.01 respectively (Gefen, Straub, \& Boudreau, 2000). 
The results revealed that $\mathrm{H} 1$ and $\mathrm{H} 2$ were higher than 1.96. The findings presented a significant relationship between reasoned action factors and customer brand engagement. This indicated that attitude towards the behaviour and subjective norm were positively related to customer brand engagement in social commerce. Thus, both $\mathrm{H} 1$ and $\mathrm{H} 2$ were supported. It was suggested that a variation inflation factor (VIF) value greater than 5 indicated a potential collinearity problem (Hair, Ringle, \& Sarstedt, 2011). In this study, the VIF value was 1.826 which was lower than 5. Additionally, the results indicated the coefficient of determination $\left(R^{2}\right)$ for customer brand engagement was 0.463 , indicating more than 46.3 percent of the construct. Next, the researchers accessed $\mathrm{Q}^{2}$ by performing blindfolding to measure the predictive relevance of the research model. In this study, the research model has predictive relevance as $Q^{2}=0.245$ was greater than zero (Chin, 1998). To test the overall fit of path model, the researchers used the following formula to get the value of GoF:

$$
\mathrm{GoF}=\sqrt{\overline{A V E}+\bar{R}^{2}}
$$

According to Fornel and Larcker (1981), GoF equal to 0.10 is small, equal to 0.25 is medium and equal to 0.36 is large. The findings reported a GoF value of 0.899 $\left(\mathrm{R}^{2}=0.463 ; \mathrm{AVE}=0.595\right)$, which exceeded the largest value of GoF 0.36. This implied that the proposed PLS model of the study was sufficient.

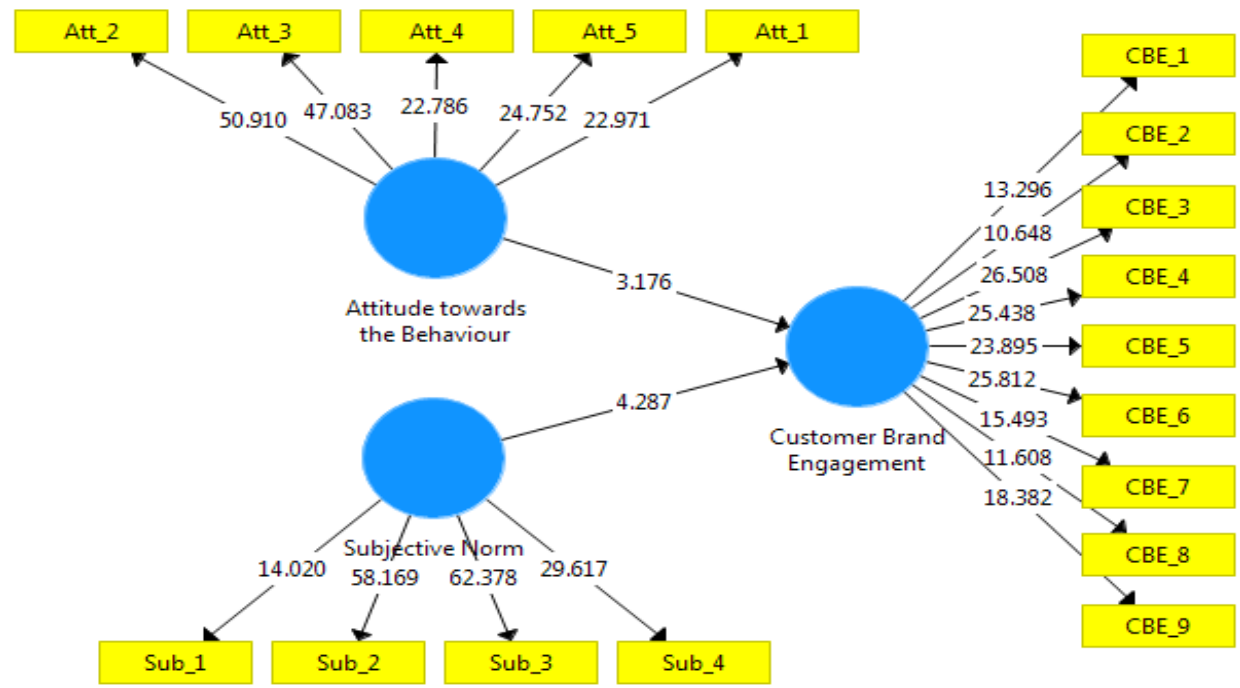

Figure 1: Overall Research Framework with t-value Source: Author

Table 5 Path Coefficients and Hypothesis Testing

\begin{tabular}{cllccl}
\hline Hypothesis & Relationship & VIF & Beta Value & t-value & Decision \\
\hline $\mathrm{H} 1$ & $\mathrm{Att} \rightarrow \mathrm{CBE}$ & 1.826 & 0.311 & $3.176^{*}$ & Supported \\
$\mathrm{H} 2$ & $\mathrm{Sub} \rightarrow \mathrm{CBE}$ & 1.826 & 0.432 & $4.287^{*}$ & Supported \\
\hline
\end{tabular}

Source: Author 


\section{Discussion}

The main idea of the study was to investigate the influences of reasoned action factors on customer brand engagement in social commerce. As expected, the findings show that attitude towards the behaviour and subjective norm have a positive relationship on customer brand engagement in social commerce. This indicated that attitude towards the behaviour and subjective norm were the factors influencing customer brand engagement in social commerce. The result is consistent with previous studies which found that attitude influences an individual's behavioural intention to engage in a particular action (Nurul Aqila Hasbullah, Abdullah Osman, Safizal Abdullah, Shahrul Nizam Salahuddin, Nor Faizzah Ramlee, \& Hazalina Mat Soha, 2016; Ramayah \& Aafaqi, 2005). In this study, social media users who have a good attitude towards a brand in social commerce might be because they believe in the quality of the brand, so they are confident to engage with that brand. This indicated that a positive attitude of customers towards a brand will increase their willingness to know more and having more interest to engage with the brand. Furthermore, the study's result is in line with many past studies that indicated the significant relationship between subjective norm and behavioural intentions (Khaled Mohammed Alqasa, Filzah Mohd Isa, Siti Norezam Othman, \& Ali Hussein Saleh Zolait, 2014; Amin \& Chong, 2011; Zainol Bindin, Kamil Mohd Idris, \& Faridahwati Mohd Shamsudin, 2009; Chen \& Yang, 2007). Evidently, many studies done in the Malaysian context found that friends, family and colleagues are the important referents in the Malaysian culture as people are more inclined to comply with their referent pressure (Zendehdel, Laily Hj Paim, \& Syuhaily Bint Osman, 2015; Ramayah \& Aafaqi, 2005). Hence, it proves that Malaysians are more concerned with the perceptions and beliefs of others who are closer to them and this will then shape a customer's decision to engage with a brand in social commerce. To this end, the study validated that the TRA can be applied to predict customer brand engagement in the context of Malaysia.

\section{Future Recommendation}

Moreover, the researchers suggested future researchers to examine this related research with other antecedents of customer brand engagement in different field (e.g. Shoppe, Tao Bao, etc). Different theories such as motivation theory and persuasive theory also can be applied in future studies. Additionally, future research also can extend the framework of the studies to explore the possible outcomes of customer brand engagement to improve the existing literature review.

\section{Conclusions and Implications}

Social commerce has become more important nowadays and many commercial activities are conducted via the Internet. It is expected that future business transactions in Sarawak will be mostly carried out in a highly interactive environment, for instance social commerce. The purpose of the study was to capture this interesting phenomenon by investigating the influence of attitude towards the behaviour and subjective norm on customer brand engagement in social commerce. The findings supported the results of previous literatures indicated that attitude towards the behaviour and subjective norm have influence on behavioural intention by showing a positive effect on customer brand engagement in social commerce. In terms of theoretical implications, this study filled 
the existing research gaps by validating new relationships between reasoned action factors (e.g. attitude towards the behaviour and subjective norm) and customer brand engagement. Hence, the study has contributed a new literature review for future researchers and academicians on customer brand engagement. Moreover, the study also enhanced the knowledge on the application of the Theory of Reasoned Action as the theoretical background to capture the behaviour of social media users towards customer brand engagement in social commerce. With regards to practical implications, this study contributed valuable insights into how the social media behaviour in Sarawak stimulates customer brand engagement and encourages social commerce business. The findings may helped to highlight some important current issues, which benefits social marketers and advertisers in their decision making especially for those in the clothes and accessories market. They have to take note that their marketing strategy should be made more effective by capturing individuals' beliefs and subjective norm aspects.

\section{References}

Ajzen, I. \& Fishbein, M. (1980). Understanding attitudes and predicting social behaviour. Englewood Cliffs, NJ: Prentice-Hall.

Ajzen, I. (1991). The theory of planned behaviour. Organizational Behaviour and Human Decision Process, 50(2), 179-211.

Al-Debei, M.M., Al-Lozi, E., \& Papazafeiropoulou, A. (2013). Why people keep coming back to Facebook: explaining and predicting continuance participation from an extended theory of planned behaviour perspective. Decision Support Systems, 55(1), 43-54.

Amin, H. \& Chong, R. (2011). Determinants for Ar-rahnu usage intentions: an empirical investigation. African Journal of Business Management, 5(20), 8181-8191.

Ayed Al-Muala., Malek Al-Majali., \& Mamdouh Al Ziadat. (2012). The usage of internet banking services among Jordanian consumers. Journal of Internet Banking and Commerce, 17(1), 1-10.

Bao, N. \& Volkovynska, A. (2016). Social Commerce: Factors that stimulate sellers to engage in C2C commercial activity on social networking platforms. Unpublished Master thesis, Lund University, Sweden.

Barclay, D., Thompson, R., \& Higgins, C. (1995). The partial least squares (PLS) approach to causal modelling: personal computer adoption and use as an illustration. Technology Studies, 2(2), 285-309.

Brodie, R.J., Hollebeek, L.D., Juric, B., \& Ilic, A. (2011). Customer engagement: conceptual domain, fundamental propositions, and implications for research in service marketing. Journal of Service Research, 14(3), 252-71.

Chen, A., Lu, Y., \& Wang, B. (2017). Customers' purchase decision-making process in social commerce: a social learning perspective. International Journal of Information Management, 37(6), 627-638.

Chen, C-C., Hsiao, K-L., \& Wu, S-J. (2018). Purchase intention in social commerce: an empirical examination of perceived value and social awareness. Library Hi Tech, 36(4), 583-604.

Chen, I. \& Yang, C. (2007). Using the theory of planned behaviour to understand inservice kindergarten teachers' behaviour to enrol in a graduate level academic program. Journal of College Teaching \& Learning, 4(1), 11-13. 
Chen, J. \& Shen, X.-L. (2015). Consumers' decisions in social commerce context: an empirical investigation. Decision Support Systems, 79(1), 55-64.

Chin, W.W. (1998). Commentary: Issues and opinion on structural equation modelling. MIS Quarterly, 22(1), 7-16.

Cronbach, L. (1951). Coefficient alpha and the internal structure of tests. Psychomerika, 16(1), 297-334.

Davis, F.D., Bagozzi, R., \& Warshaw, P. (1989). User acceptance of computer technology: a comparison of two theoretical models. Management Science, 35(8), 982-1003.

Evans, D. (2010). Social media marketing: the next generation of business engagement. International Journal of Management Research and Review, 3(2), 2461-2468.

Fishbein, M. \& Ajzen, I. (1975). Belief, attitude, intention, and behaviour: an introduction to theory and research. United State: Addison-Wesley.

Fornell, C. \& Larcker, D. (1981). Evaluating structural equation models with unobservable variables and measurement error. Journal of Marketing Research, 18(3), 39-50.

Gan, C. \& Wang, W. (2017). The influence of perceived value on purchase intention in social commerce context. Internet Research, 27(4), 772-785.

Gefen, D., Straub, D.W., \& Boudreau, M.C. (2000). Structural equation modelling and regression: guidelines for research practice. Communications of the Association for Information Systems, 4(7), 2-76.

Goh, S.L., Suddin Bin Lada., Mohd Zulkifli Muhammad., Abang Asri Haji Abang Ibrahim., \& Amboala, T. (2011). An exploration of social networking sites (SNS) adoption in Malaysia using technology acceptance model (TAM), theory of planned behaviour (TPB) and intrinsic motivation. Journal of Internet Banking and Commerce, 16(2), 1-27.

Gold, A.H., Malhotra, A., \& Segars, A.H. (2001). Knowledge management: an organizational capabilities perspective. Journal of Management, 18(1), 185-214.

Gummerus, J., Liljander, V., Weman, E., \& Pihlstrom, M. (2012). Customer engagement in a Facebook brand community. Management Research Review, 35(9), 857-877.

Hair, J.F., Ringle, C.M., \& Sarstedt, M. (2011). PLS-SEM: Indeed a sliver bullet. The Journal of Marketing Theory and Practice, 19(2), 139-152.

Hair, J.F., Wolfinbarger, M.F., Ortinau, D.J., \& Bush, R.P. (2010). Essentials of marketing research (2nd ed.). New York: McGraw-Hill.

Hajli, N., Sims, J., Zadeh, A.H., \& Richard, M-O. (2017). A social commerce investigation of the role of trust in a social networking site on purchase intentions. Journal of Business Research, 71(2017), 133-141.

Ho, S.S., Liao, Y., \& Rosenthal, S. (2015). Applying the theory of planned behaviour and media dependency theory: predictors of public pro-environmental behavioural intentions in Singapore. Environmental Communications A Journal of Nature and Culture, 9(1), 77-99.

Huang, Y.-M. (2016). Exploring the intention to use cloud services in collaboration contexts among Taiwan's private vocational students. Information Development, 33(1), 29-42.

Khaled Mohammed Alqasa., Filzah Mohd Isa., Siti Norezam Othman., \& Ali Hussein Saleh Zolait. (2014). The impact of students' attitude and subjective norm on the behavioural intention to use services of banking system. International Journal of Business Information Systems, 15(1), 105-122. 
Kline, R.B. (2011). Principles and Practice of Structural Equation Modelling. Guilford Press, New York.

Lada, S., Tanakinjal, G.H., \& Amin, H. (2009). Predicting intention to choose halal products using theory of reasoned action. International Journal of Islamic and Middle Eastern Finance and Management, 2(1), 66-76.

Leong, L-Y., Noor Ismawati Jaafar., \& Sulaiman Ainin. (2018). Understanding Facebook commerce (f-commerce) actual purchase from an artificial neural network perspective. Journal of Electronic Commerce Research, 19(1), 75-103.

Lujja, S., Omar Mohammad, M., \& Hassan, R. (2016). Modelling public behavioural intention to adopt Islamic banking in Uganda: the theory of reasoned action. International Journal of Islamic and Middle Eastern Finance and Management, 9(4), 583-600.

Maia, C., Lunardi, G., Longaray, A., \& Munhoz, P. (2018) Factors and characteristics that influence consumers' participation in social commerce. Revista de Gestão, 25(2), 194-211.

Muhamad Abduh., Jarita Duasa., \& Mohd Azmi Omar. (2011). Factors influence depositors' withdrawal behaviour in Islamic banks: a theory of reasoned action. World Academy of Science, Engineering and Technology, 5(12), 1813-1818.

Nurul Aqila Hasbullah., Abdullah Osman., Safizal Abdullah., Shahrul Nizam Salahuddin., Nor Faizzah Ramlee., \& Hazalina Mat Soha. (2016). The relationship of attitude, subjective norm and website usability on consumer intention to purchase online: an evidence of Malaysian youth. Procedia Economics and Finance: 7th International Economics \& Business Management Conference, 5th \& 6th October, 35, 493-502.

Potgieter, L.M. \& Naidoo, R. (2017). Factors explaining user loyalty in social mediabased brand community. South African Journal of Information Management, 19(1), 1-9.

Ramayah, T. \& Aafaqi, B. (2005). Intention to shop online amongst MBA students: applicability of the theory of reasoned action (TRA). Proceedings of International Conference on e-Commerce (ICoEC) 2005, 10-11 January, The Summit Hotel, Subang USJ, Selangor, Malaysia, 43-47.

Ranjan, K.R. \& Read, S. (2014). Value co-creation: Concept and measurement. Journal of the Academy of Marketing Science, 44(3), 290-315.

Reitz, A.R. (2012). Online consumer engagement: understanding the antecedents and outcomes. Unpublished PhD thesis, Colorado State University, Fort Collins, Colorado.

Roscoe, J.T. (1975). Fundamental research statistics for the behavioural sciences (2nd ed.). New York: Holt Rinehart \& Winston.

Sable, M., Schwartz, L., Kelly, P., Lisbon, E., \& Hall, M. (2006). Using the theory of reasoned action to explain physician intention to prescribe emergency contraception. Perspectives on Sexual and Reproductive Health, 38(1), 20-7.

Sanne, P.N.C. \& Wiese, M. (2018). The theory of planned behaviour and user engagement applied to Facebook advertising. South African Journal of Information Management, 20(1), 1-10.

Schamari, J. \& Schaefers, T. (2015). Leaving the home turf: How brands can use Webcare on consumer-generated platforms to increase positive consumer engagement. Journal of Interactive Marketing, 30(1), 20-33. 
Sekaran, U. \& Bougie, R. (2009). Research methods for business: A skill building approach (5th ed.). John Wiley \& Sons, Inc.

Sharma, S. \& Crossler, R.E. (2014). Disclosing too much? Situational factors affecting information disclosure in social commerce environment. Electronic Commerce Research and Applications, 13(5), 305-319.

Solem, B.A.A. \& Pedersen, P.E. (2016). The role of customer brand engagement in social media: conceptualization, measurement, antecedents and outcomes. International Journal of Internet Marketing and Advertising, 10(4), 223-254.

Tan, G.W.-H., Ooi, K.-B., Sim, J.-J., \& Phusavat, K. (2012). Determinants of mobile learning adoption: an empirical analysis. The Journal of Computer Information Systems, 52(3), 82-91.

Teo, T. (2009). The impact of subjective norm and facilitating conditions on pre-service teachers' attitude toward computer use: a structural equation modelling of an extended technology acceptance model. Journal educational computing research, 40(1), 89-109.

Wong, K.-T., Rosma binti Osman, Goh, P.S.C., \& Mohd Khairezan Rahmat. (2013). Understanding student teachers' behavioural intention to use technology: technology acceptance model (TAM) validation and testing. International Journal of Instruction, 6(1), 89-104.

Zainol Bindin., Kamil Mohd Idris., \& Faridahwati Mohd Shamsudin. (2009). Predicting compliance intention on Zakah on employment income in Malaysia: an application of reasoned action theory. Journal Penguruan, 28(1), 85-102.

Zendehdel, M., Laily Hj Paim., \& Syuhaily Bint Osman. (2015). Students' online purchasing behaviour in Malaysia: understanding online shopping attitude. Cogent Business and Management, 2, 1-13.

Zhang, H., Lu, Y., Gupta, S., \& Zhao, L. (2014). What motivates customers to participate in social commerce? The impact of technological environment and virtual customer experiences. Information \& Management, 51(8), 1017-1030.

Zhou, L., Zhang, P., \& Zimmermann, H.-D. (2013). Social commerce research: an integrated view. Electronic Commerce Research and Applications, 12(2), 61-68. 